\author{
Павло Кобилін \\ к. геогр. н., дочент кафедри соиіально-економічної географії і регіонознавства, \\ Харківський національний університет імені В.Н. Каразіна, майдан Свободи, 4, м. Харків, 61022, Украӥна \\ e-mail: kobilin333@gmail.com, ORCID ID: https://orcid.org/0000-0001-9718-5838

\begin{abstract}
Наталія Добровольська
к. геогр. н., доцент кафедри туристичного та готельного бізнесу,

Харківський торговельно-економічний інститут КНТЕУ, пров. Отакара Яроша, 8, м. Харків, 61045, Украӥна дочент кафедри соиіально-економічної географії і регіонознавства,

Харківський національний університет імені В.Н. Каразіна, майдан Свободи, 4, м. Харків, 61022, Украӥна e-mail: natalie.dobrovolskava@gmail.com, ORCID ID: http://orcid.org/0000-0001-5583-2179
\end{abstract}

\section{Ірина Скриль} \\ к. геогр. н., дочент кафедри сочіально-економічної географії і регіонознавства, \\ Харківський наиіональний університет імені В.Н. Каразіна, майдан Свободи, 4, м. Харків, 61022, Украӥна \\ e-mail: skril403@gmail.com, ORCID ID: https://orcid.org/0000-0002-2010-0872

\section{Володимир Редін} \\ к. геогр. н., доцент кафедри соиіально-економічної географії і регіонознавства, \\ Харківський наиіональний університет імені В.Н. Каразіна, майдан Свободи, 4, м. Харків, 61022, Украӥна \\ e-mail: vadim.redin@karazin.ua, ORCID ID: https://orcid.org/0000-0002-1580-7662

\section{ВИЯВЛЕННЯ ПРОСТОРОВИХ ОСОБЛИВОСТЕЙ РОЗВИТКУ ТОРГОВЕЛЬНОГО ОБСЛУГОВУВАННЯ НАСЕЛЕННЯ У ХАРКІВСБКІЙ ОБЛАСТІ ЗА ДОПОМОГОЮ ОДНОВИМІРНОГО СТАТИСТИЧНОГО АНАЛІЗУ}

У статті характеризуються просторові особливості розвитку торговельного обслуговування населення у Харківській області за допомогою одновимірного статистичного аналізу. Харківська область як один з найбільш розвинутих регіонів України характеризується високим ступенем моноцентричності регіонального розвитку. Для оцінки цього ступеню обрано одновимірний статистичний аналіз. Одновимірний статистичний аналіз - вид статистичного аналізу, що використовується для характеристики розподілу однієї змінної. Характеристиками розподілу значень обрано такі параметри описової статистики: медіана, мода, середне арифметичне значення, дисперсія, середньоквадратичне відхилення, коефіцієнт варіації, коефіцієнт асиметрії, коефіцієнт ексцесу. У статті характеризувалися такі показники як чисельність населення, кількість закладів торгівлі, кількість закладів ресторанного господарства у населених пунктах регіону. За ідеальний розподіл значень показників взято нормальний розподіл випадкової величини, за яким мають дорівнювати між собою медіана, мода та середнє арифметичне значення, а коефіцієнти асиметрії та ексцесу мають дорівнювати 0.

За результатами одновимірного статистичного аналізу встановлено, що у Харківській області розподіл вищезгаданих показників не відповідає нормальному розподілу, він є вкрай нерівномірний, що підтверджує моноцентринчність регіонального розвитку. Розподіл показників чисельності населення, кількості об'єктів торгівлі, об'єктів ресторанного господарства подібний між собою, що свідчить про обумовленість наявної мережі закладів торгівлі, ресторанного господарства чисельністю населення у населених пунктах. Проведено аналіз параметрів описової статистики у розрізі новосформованих адміністративних районів Харківської області та встановлено, що для жодного району не характерний нормальний розподіл вищезгаданих показників, проте найбільш віддаленим від нормального розподілу є Харківський район, а наближеними є Богодухівський, Чугуївський, Красноградський райони.

Ключові слова: одновимірний статистичний аналіз, роздрібна торгівля, ресторанне господарство, поліцентричний розвиток, моноцентричний розвиток, нормальний розподіл, параметри описової статистики.

Павел Кобылин, Наталья Добровольская, Ирина Скрыль, Владимир Редин. ВЫЯВЛЕНИЕ ПРОСТРАНСТВЕННЫХ ОСОБЕННОСТЕЙ РАЗВИТИЯ ТОРГОВОГО ОБСЛУЖИВАНИЯ НАСЕЛЕНИЯ В ХАРЬКОВСКОЙ ОБЛАСТИ С ПОМОЩЬЮ ОДНОМЕРНОГО СТАТИСТИЧЕСКОГО АНАЛИЗА

В статье характеризуются пространственные особенности развития торгового обслуживания населения в Харьковской области с помощью одномерного статистического анализа. Харьковская область как один из наиболее развитых регионов Украины характеризуется высокой степенью моноцентричности регионального развития. Для оценки этой степени избран одномерный статистический анализ. Одномерный статистический анализ - это вид статистического анализа, используемый для характеристики распределения одной переменной. Характеристиками распределения значений выбраны следующие параметры описательной статистики: медиана, мода, среднее арифметическое значение, дисперсия, стандартное отклонение, коэффициент вариации, коэффициент асимметрии, коэффициент эксцесса. В статье характеризовались такие показатели как: численность населения, количество предприятий торговли, количество заведений ресторанного хозяйства в населенных пунктах региона. За идеальное распределение значений показателей взято нормальное распределение случайной

(С Кобилін П., Добровольська Н., Скриль І., Редін В., 2020 
величины, согласно которому медиана, мода и среднее арифметическое значение должны быть равны между собой, а коэффициенты асимметрии и эксцесса должны равняться 0.

По результатам одномерного статистического анализа определено, что в Харьковской области распределение вышеупомянутых показателей не соответствует нормальному распределению, оно крайне неравномерно, что подтверждает моноцентринчнисть регионального развития. Распределение показателей численности населения, количества объектов торговли, объектов ресторанного хозяйства подобно между собой, что свидетельствует об обусловленности имеющейся сети предприятий торговли, ресторанного хозяйства численности населения в населенных пунктах. Проведен анализ параметров описательной статистики в разрезе новосформированных административных районов Харьковской области и установлено, что ни для одного района не характерно нормальное распределение вышеупомянутых показателей, однако наиболее удаленными от нормального распределения является Харьковский район, а наиболее приближенны Богодуховский, Чугуевский, Красноградский районы.

Ключевые слова: одномерный статистический анализ, розничная торговля, общественное питание, полицентрическое развитие, моноцентрическое развитие, нормальное распределение, параметры описательной статистики.

Pavlo Kobylin, Nataliia Dobrovolska, Iryna Skryl, Volodymyr Redin. SPATIAL FEATURES IDENTIFICATION OF THE POPULATION TRADING SERVICE DEVELOPMENT IN KHARKIV REGION WITH THE USE OF THE UNIVARIATE STATISTICAL ANALYSIS

The paper describes spatial features identification of the population trading service development in Kharkiv region with the use of the univariate statistical analysis. Kharkiv region as one of the most developed regions of Ukraine is characterized by a high degree of monocentric regional development. The univariate statistical analysis was chosen in order to assess this degree. Univariate statistical analysis is a type of statistical analysis used to characterize the distribution of a single variable. The following parameters of descriptive statistics were selected as characteristics of the values distribution: median, mode, mean, variance, standard deviation, coefficient of variation, coefficient of skewness, and coefficient of kurtosis. Such indicators are characterized in the paper: a number of population, a number of trade enterprises, a number of restaurant facilities in the settlements of the region. The normal distribution of a random variable was taken for the ideal distribution of the indicators values. The distribution is normal if the median, mode and mean are equal to each other, the coefficients of skewness and kurtosis should equal 0.

According to the results of a univariate statistical analysis, it was determined that the distribution of the above mentioned indicators don't correspond to a normal distribution, it is extremely uneven, which confirms the monocentricity of regional development in Kharkiv region. Distribution of indicators of the number of population, trade enterprises, and restaurant facilities is similar to each other, which indicates conditionality of the existing network of trade enterprises, restaurant facilities to the population in settlements. The analysis of the descriptive statistics parameters in the context of the newly formed administrative districts of Kharkiv region was carried out and it was found that any district isn't characterized by the normal distribution of the above indicators, however, the most distant from the normal distribution is Kharkiv district, the most closed are Bogodukhivsky, Chuhuivsky, Krasnohradsky districts.

Key words: univariate statistical analysis, retail trade, restaurant industry, polycentric development, monocentric development, normal distribution, descriptive statistics parameters.

Вступ. Важливим аспектом соціальноекономічного розвитку держави чи регіону є його пропорційний розвиток. Мова йде про рівномірний розподіл продуктивних сил по території держави чи регіону. Рівномірний розвиток економіки дає можливість рівного доступу людей до матеріальних благ. Харківська область, яка посіла 6-е місце за результатами моніторингу соціально-економічного розвитку регіонів України за 2019 рік, проведеного Міністерством розвитку громад та територій [13], характеризується значною моноцентричністю системи розселення, про що наголошується в Стратегії розвитку Харківської області на період до 2020 року [22]. В Стратегії вказується, що 53,5\% населення регіону проживає у м. Харкові, а другий за величиною населений пункт регіону (м. Лозова) у 20 разів менший за обласний центр, що не має аналогів в Україні. Крім того, обласний центр має ексцентричне розташування в регіоні. Все це спричинює високий рівень господарської діяльності та людського капіталу в обласному центрі та позбавляє можливостей розвитку найбільш віддалених територій регіону. Тому Стратегією пропонується перехід до поліцентричної моделі просторового розвитку, що дасть можливості для забезпечення 1,5-годинного доступу населення до установ обслуговування та формування інвестиційно привабливих точок соціально-економічного зростання. Нові точки росту отримують нові функції, які раніше були притаманні лише обласному центру, забезпечать те- риторії свого впливу доступом до фінансових ресурсів, науково-освітніх, медичних, культурних, торговельних послуг тощо. Такими точками мають стати м. Куп'янськ, м. Ізюм, м. Лозова [22].

На час написання даної статті термін реалізації стратегії завершився, тому дуже важливо проаналізувати ступінь моноцентричності/поліцентричності регіонального розвитку в нових умовах. Крім того, у 2020 р. урядом було ліквідовано існуючі до цього та створено нові адміністративні райони. У Харківській області було сформовано 7 районів замість 27 [21]. Отже, грунтовний аналіз новостворених районів $€$ дуже важливим та актуальним для виявлення особливостей розвитку найбільш віддалених територій області. Найбільш доцільним, на наш погляд, буде суспільно-географічне дослідження, які характеризують особливості протікання тих чи інших процесів на певних територіях регіону, а грунтовність дослідження може бути забезпечена за допомогою використання статистичних методів. На прикладі торговельного обслуговування населення буде оцінюватися ступінь моноцентричності/поліцентричності регіонального розвитку.

Аналіз попередніх досліджень. Питання переходу до поліцентричного регіонального розвитку доволі широко досліджується у наукових колах. Так, Дж. Фрідманом ці питання розглядаються в аспекті моделі «центр-периферія» [26], Ф. Перру - в рамках теорії «полюсів розвитку» та «центрів зростання» 
[28], Д. Пептенату впорядкував центри поляризації за показниками демографічної привабливості, рівня економічного розвитку та конкурентоспроможності [29]; П. Венери и Д. Бургалассі використовують індекс ентропії як індикатор рівня поліцентричного розвитку регіону та індекс поліцентричності як ступінь центральності кожного з вузлів [31]. І.О. Пилипенком встановлено суспільно-географічну сутність парної категорії «центр-периферія», систематизовано центро-периферійні процеси і структури [19]. Нємець К., Нємець Л. та ін. використовували метод ІФВ-моделювання для визначення ступеня поліцентричності / моноцентричності Харківської області [27]. О.М. Голвазіним класифіковано територіальні рівні поліцентричності з огляду на мету політики, порівняно результати моделі «ранг-розмір» індексом людського розвитку країн світу, обсягом валової доданої вартості, площ зон обслуговування, розроблено заходи державної політики адаптації міст і районів України та концептуальну модель державної політики поліцентричного розвитку України [3]. Нємцем К., Сегідою К., Гусєвою Н. проаналізовано міста Харківської області з точки зору моноцентричної / поліцентричної моделі просторового розвитку з використанням ІФВ-моделювання, центрографічного методу, моделі «ранг-розмір» та визначено міста Харківської області як центри поліцентричної моделі просторового розвитку регіону (міста Харків, Лозова, Ізюм, Чугуїв, Первомайський) [14].

Статистичні методи у суспільно-географічних дослідженнях системи торговельного обслуговування населення регіону, сфери послуг в цілому використовуються дуже широко. В.П. Іванченком використовувався коефіцієнт тяжіння для визначення ступеня тяжіння покупців до того чи іншого району міста Донецької області [7]; O.I. Кочерга за допомого кореляційного аналізу визначав зв'язок між людністю міст та структурою підприємств торгівлі [23], М.О. Барановським за допомогою кореляційного, факторного, регресійного аналізу було встановлено особливості взаємозв'язків різних факторів розвитку пересувних форм обслуговування населення [1]. Кластерний аналіз використовувався для типізації регіонів України та інших країн світу за рівним розвитку торгівлі у роботах Є.Ю. Колосинського [9], M.O. Барановського [1], S. Sroda-Murawka, D. Szymanska [30], Корнус О.Г. [10], Кобиліна П.О. [8] та ін. вчених, різні інтегральні показники для групування районів регіонів України використовувалися у роботах Осіпчук І.О. [16], Білоконя Т.Г. [2], Корнус О.Г. [10]. Запотоцькою І.В. за допомогою методу побудови статистичних поверхонь встановлено головні ядра, буферну зону та периферійні території соціальної сфери Черкаської області [6]. Одновимірний статистичний аналіз у суспільногеографічних дослідженнях використовується не досить активно, у тому числі у дослідженнях торгівлі, він описується у роботах з математичних і статистичних методів досліджень у суспільній географії (у роботах Грицевича В.С. [5], Голікова А.П., Черваньова І.Г. [4], Нємця К.А., Нємець Л.М. [15], Шаблія O.I. [25] тощо.

Метою дослідження $є$ характеристика просто- рових особливостей розвитку торговельного обслуговування населення у Харківській області за допомогою методів одновимірного статистичного аналі3y.

Методика дослідження. Основою для даного дослідження виступає одновимірний статистичний аналіз. Одномірні статистичні методи (Univariate techniques) - методи статистичного аналізу даних у випадках, якщо існує єдиний вимірювач для оцінки кожного елемента вибірки, або якщо цих вимірників декілька, але кожна змінна аналізується окремо від усіх інших [12]. Іншими словами, для аналізу використовується одна змінна для сукупності об'єктів. У нашому випадку змінними будуть чисельність населення, кількість закладів торгівлі, об'єктів ресторанного господарства. Об'єктами виступатимуть населені пункти, за якими надаються дані щодо чисельності населення, кількості об'єктів торгівлі, ресторанного господарства. Одновимірний статистичний аналіз має у своєму арсеналі багато методів, у нашому дослідженні ми зупинимося на описовій статистиці. Основними статистичними показниками, які використовуються для опису набору даних, $є$ : середнє значення, медіана, мода, стандартне відхилення, дисперсію, мінімальне та максимальне значення змінної, розмах варіації, коефіцієнт ексцесу та коефіцієнт асиметрії.

Розглянемо більш детально характеристики розподілу.

Медіана (Мe) - «...середнє значення ознаки у ранжируваному ряду варіант, тобто значення, рівновіддалене від початку та кінця варіаційного ряду» [4, c. 21]. Якщо число варіант непарне, медіана відповідає конкретній величині. Якщо число варіант парне, то медіана розраховується як середнє арифметичне двох центральних значень. Таким чином, медіана поділяє ранжируваний ряд на дві однакові частини. Кожну поділену частину поділяють також на дві частини і отримані медіани називають квартилями. Нижній (перший) квартиль знаходиться у першій половині варіаційного ряду (25-й процентиль - 25\% значень варіаційного ряду), верхній (другий) - у другій (75-й процентиль - 25\% значень варіаційного ряду) [12].

За допомогою гра́фіку «я́щик з ву́сами» (box \& whisker plot) відображається розподіл значень показників через їх квантилі. Відображаються максимальні та мінімальні значення, медіана, нижній (перший) та верхній (другий) квартилі [12].

Мода (Mo) - це значення ознаки, що зустрічається найбільше у варіаційному ряду.

Середнє арифметичне значення (Meаn) - відношення суми всіх значень варіаційного ряду до кількості елементів ряду.

Дисперсія $\left(\delta^{2}\right)$ - величина, яка характеризує ступінь розсіювання значень показника щодо середнього значення розподілу.

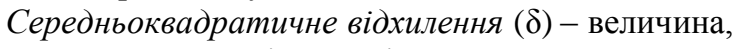
яка характеризує ступінь розсіювання значень показника щодо середнього значення розподілу. Розраховується як корінь квадратний від дисперсії.

Коефіцієнт варіаціï - відносна величина, яка характеризує ступінь розсіювання змінної та розра- 
ховується як відношення середнього квадратичного відхилення $\delta$ до середнього арифметичного Mean.

Коефіuієнт асиметрї (Skewness, As) - величина, що характеризує асиметрію розподілу певної змінної. Коефіцієнт асиметрії додатній, якщо «довша частина» кривої знаходиться праворуч від середнього значення розподілу; коефіцієнт асиметрії від'ємний у протилежному випадку.

Koефiuiєнт ексиесу (Kurtosis, Es) - міра гостроти піку розподілу змінної. Коефіцієнт ексцесу додатній, якщо крива розподілу має «гострішу» вершину ніж вершина кривої нормального розподілу (вершина знаходиться вище вершини кривої нормального розподілу), коефіцієнт ексцесу від'ємний у протилежному випадку [4].

Розподіл значень повинен відповідати нормаль- ному розподілу. Нормальний розподіл виникає тоді, коли дана величина є сумою великого числа незалежних випадкових величин, кожна з яких відіграє незначну роль в утворенні всієї суми. Він є граничним законом, до якого наближаються інші закони розподілу [24]. Тобто розподіл значень певного показника має бути рівномірним.

Форма нормальної кривої має вид одновершинної симетричної кривої, іiї гілки асимптотично наближаються до осі абсцис. Будь-яка нормальна крива має форму "дзвона", має випуклість, що спрямована вгору до точки максимуму [24]. При нормальному розподілі середня арифметична, мода і медіана будуть рівними між собою [11]. Також дисперсія має бути більше 0, а коефіцієнти асиметрії, ексцесу дорівнювати 0 .

$$
\begin{aligned}
& \sigma^{2}>0 \\
& \text { Mean }=\mathrm{Mo}=\mathrm{Me} \\
& \text { As }=0 \\
& \mathrm{Es}=0 \\
& \sigma=1 \text { - стандартний нормальний розподіл }
\end{aligned}
$$

Слід зауважити, що статистичні дані (чисельність населення, кількість об'єктів торгівлі, ресторанного господарства) представлені у розрізі населених пунктів регіону за 2019 р. Проте розрахунки параметрів описової статистики здійснювалися за новим адміністративно-територіальним устроєм Харківської області, відповідно до Розпорядження Кабінету Міністрів України № 725-р від 12 червня 2020 p. «Про визначення адміністративних центрів та затвердження територій територіальних громад Харківської області» та Постанови Верховної Ради України № 807-IX «Про утворення та ліквідацію районів» від 17.07.2020 р., тобто у розрізі 56 новоутворених територіальних громад та 7 новоутворених адміністративних районів. Розрахунки параметрів описової статистики здійснювалося в програмному пакеті MiniTab.

Результати дослідження. Авторами було проведено одновимірний статистичний аналіз показників чисельності населення населених пунктів Харківської області, кількості закладів роздрібної торгівлі та об'єктів ресторанного господарства, розраховано параметри описової статистики. Отримані значення відображені у таблиці 1.

Таблиця 1

\begin{abstract}
Показники розподілу значень показників чисельності населення, кількості закладів торгівлі, закладів ресторанного господарства по населеним пунктам Харківської області за 2019 р. (складено авторами за даними [17, 18])
\end{abstract}

\begin{tabular}{|l|c|c|c|}
\hline & $\begin{array}{c}\text { Чисельність } \\
\text { населення, осіб }\end{array}$ & $\begin{array}{c}\text { Кількість } \\
\text { закладів } \\
\text { торгівлі, } \\
\text { одиниць }\end{array}$ & $\begin{array}{c}\text { Кількість } \\
\text { закладів } \\
\text { ресторанного } \\
\text { господарства, } \\
\text { одиниць }\end{array}$ \\
\hline Мінімальне значення (Min) & 0 & 0 & 0 \\
\hline Нижній квартиль & 49 & 0 & 0 \\
\hline Середнє арифметичне значення (Mean) & 1554,95 & 13,08 & 2,62 \\
\hline Медіана (Ме) & 159 & 1 & 0 \\
\hline Верхній квартиль & 447,5 & 2 & 1 \\
\hline Максимальне значення (Мах) & 1433320 & 13924 & 0 \\
\hline Мода (Мо) & 32 & 0 & 4526,13 \\
\hline Дисперсія (D) & 1189414130,3 & 112143,3 & 2563,2 \\
\hline Коефіцієнт варіації & 2217,94 & 2560,93 & 67,28 \\
\hline Середньоквадратичне відхилення $(\sigma)$ & 34487,88 & 334,88 & 41,52 \\
\hline Коефіцієнт асиметрії (As) & 41,20067 & 41,27466 & 1729,24 \\
\hline Коефіцієнт ексцесу (Еs) & 1711,041 & 1715,215 & \\
\hline
\end{tabular}


Мінімальне значення розподілу згаданих показників свідчить проте, що у Харківській області існують населені пункти, у яких відсутнє постійне населення, що перебуває у стадії зняття з обліку, а також відсутні заклади роздрібної торгівлі та об'єкти ресторанного господарства. Це стосується населених пунктів, у яких дуже мала чисельність населення. Середне арифметичне значення у показника чисельності населення становить 1555 осіб, при цьому медіана - 159 осіб. Нижній квартиль за показником чисельності населення складає 49 осіб, а верхній квартиль - 447,5 осіб. Тобто, у 25\% населених пунктів чисельність населення не перевищує 49 осіб, у $50 \%$ населених пунктів чисельність населення не перевищує 159 осіб, а у 75\% населених пунктів чисельність населення не перевищує 448 осіб, при цьому максимальна чисельність населення у м. Харкові 1,4 млн. осіб. Звідси випливає, що медіана не дорів- нює середньому арифметичному значенню, отже, розподіл значень не підкоряється нормальному розподілу. За параметрами описової статистики побудовано діаграму розмаху (box \& whisker plot) чисельності населення у населених пунктах Харківської області (рис. 1), що наочно відображає розподіл. 3 нього видно, що м. Харків дуже сильно вибивається із загальної вибірки та свідчить про значну моноцентричність міста у регіоні. Така ж ситуація характерна i для кількості закладів торгівлі (таблиця 1, рис. 2), та кількості закладів ресторанного господарства (таблиця 1, рис. 3). За модою ми можемо виявити, яких значень параметрів у вибірці нараховується найбільша кількість. У чисельності населення це 36 осіб, а у кількості закладів торгівлі та закладів ресторанного господарства 0, тобто об'єкти торгівлі і ресторанного господарства відсутні.

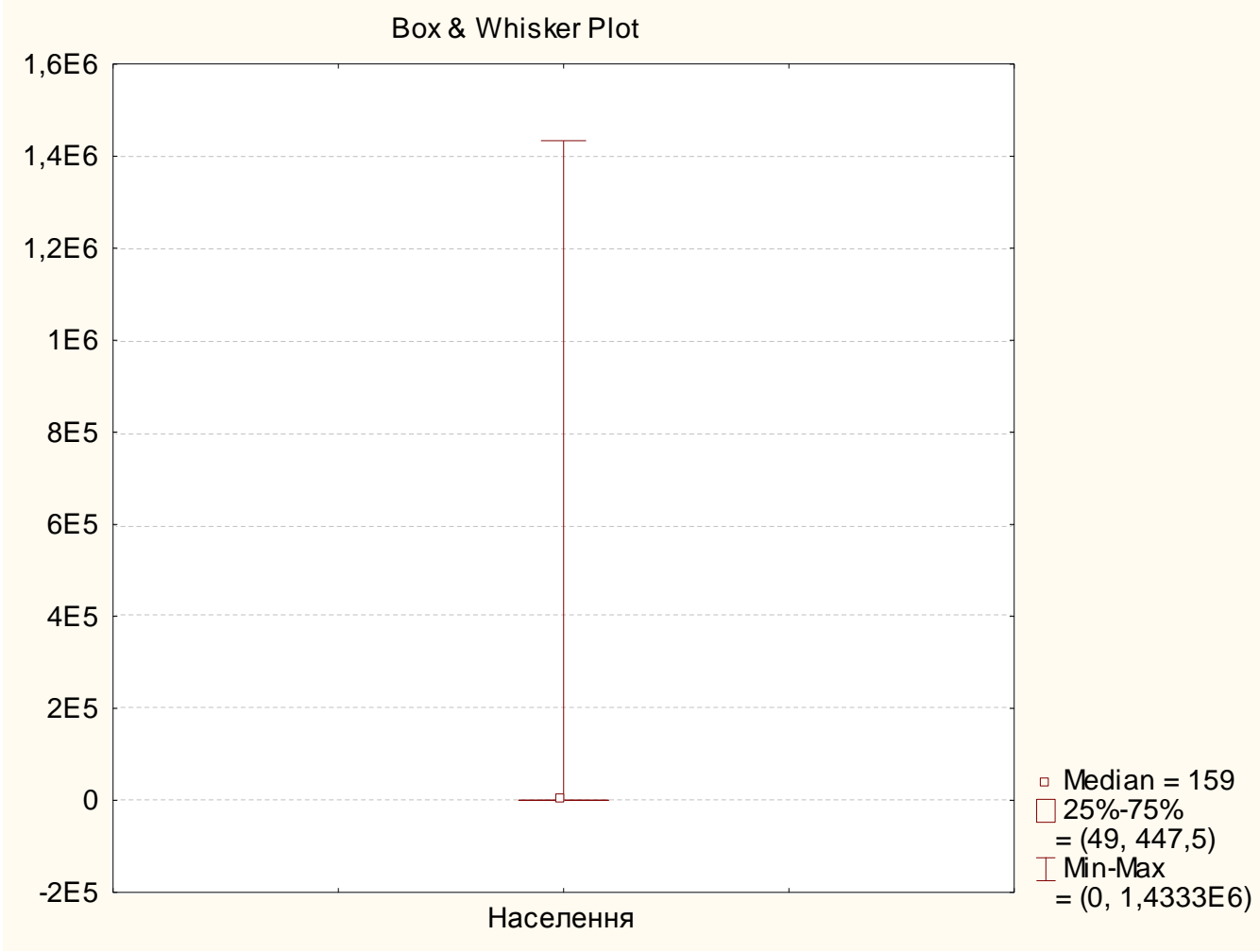

Рис. 1. Діаграма розмаху (box \& whisker plot) чисельності населення у населених пунктах Харківської області за 2019 р. (складено авторами за даними $[17,18]$ )

Ступінь моноцентричності дуже добре відображають наступні параметри описової статистики: дисперсія, стандартне відхилення та коефіцієнт варіації. Ці параметри характеризують ступінь розсіювання показників чисельності населення, кількості об'єктів торгівлі і ресторанного господарства за населеними пунктами. 3 таблиці 1 видно, що значення параметрів дуже високі (так, дисперсія для чисельності населення складає 1189414130,3, для об'єктів торгівлі - 112143,3, для ресторанного господарства 4526,13). Коефіцієнт варіації, як вже зазначалося, $є$ відносними показником, тому його значення краще характеризує ступінь розсіювання. Його значення більш-менш подібне в залежності від показників (так, коефіцієнт варіації для чисельності населення складає 2217,94, для об’єктів торгівлі - 2560,93, для ресторанного господарства - 2563,2). Тобто можна допустити, що розподіл значень кількості об'єктів роздрібної торгівлі та об'єктів ресторанного господарства відповідає розподілу чисельності населення у населених пунктах регіону.

Отримані результати характеристик розподілу значень показників чисельності населення, кількості закладів торгівлі, закладів ресторанного господарства по населеним пунктам Харківської області показали, що їх розподіл не відповідає нормальному (рис. $4,5,6$ ). Так, середнє арифметичне значення не відповідає моді та медіані, а коефіцієнти асиметрії та 
ексцесу не дорівнюють 0 (так, для чисельності населення коефіцієнт асиметрії складає 41,2, а коефіцієнт ексцесу - 1711, для об'єктів торгівлі - 41,3 та 1715,2 відповідно, для ресторанного господарства - 41,52 та 1729,2 відповідно (таблиця 1). Все це свідчить про значний нерівномірний розподіл чисельності населення, кількості закладів торгівлі, закладів ресторанного господарства по населеним пунктам Харківської області.

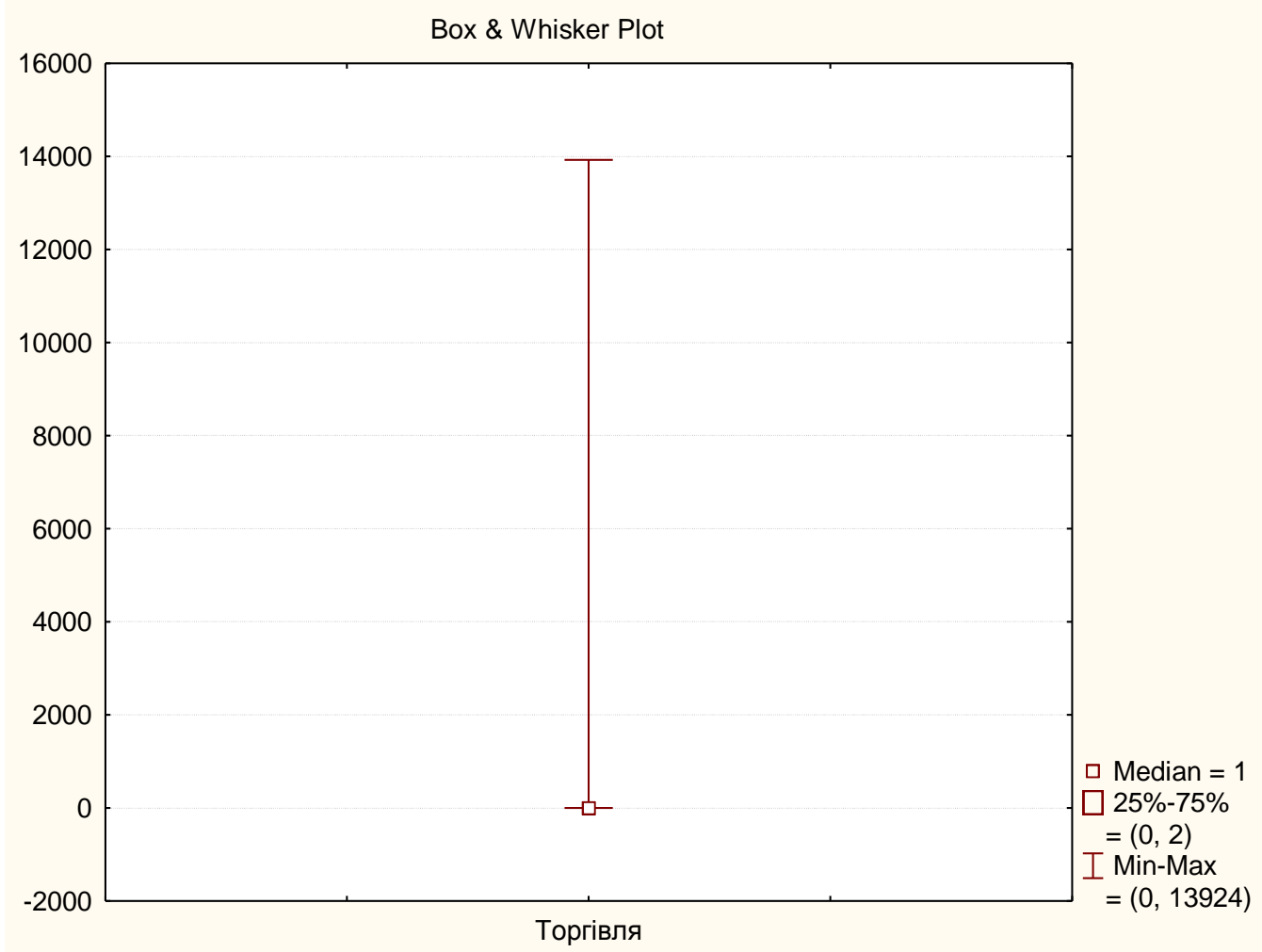

Рис. 2. Діаграма розмаху (bох \& whisker plot) кількості закладів торгівлі у населених пунктах Харківської області за 2019 р. (складено авторами за даними [17,18])

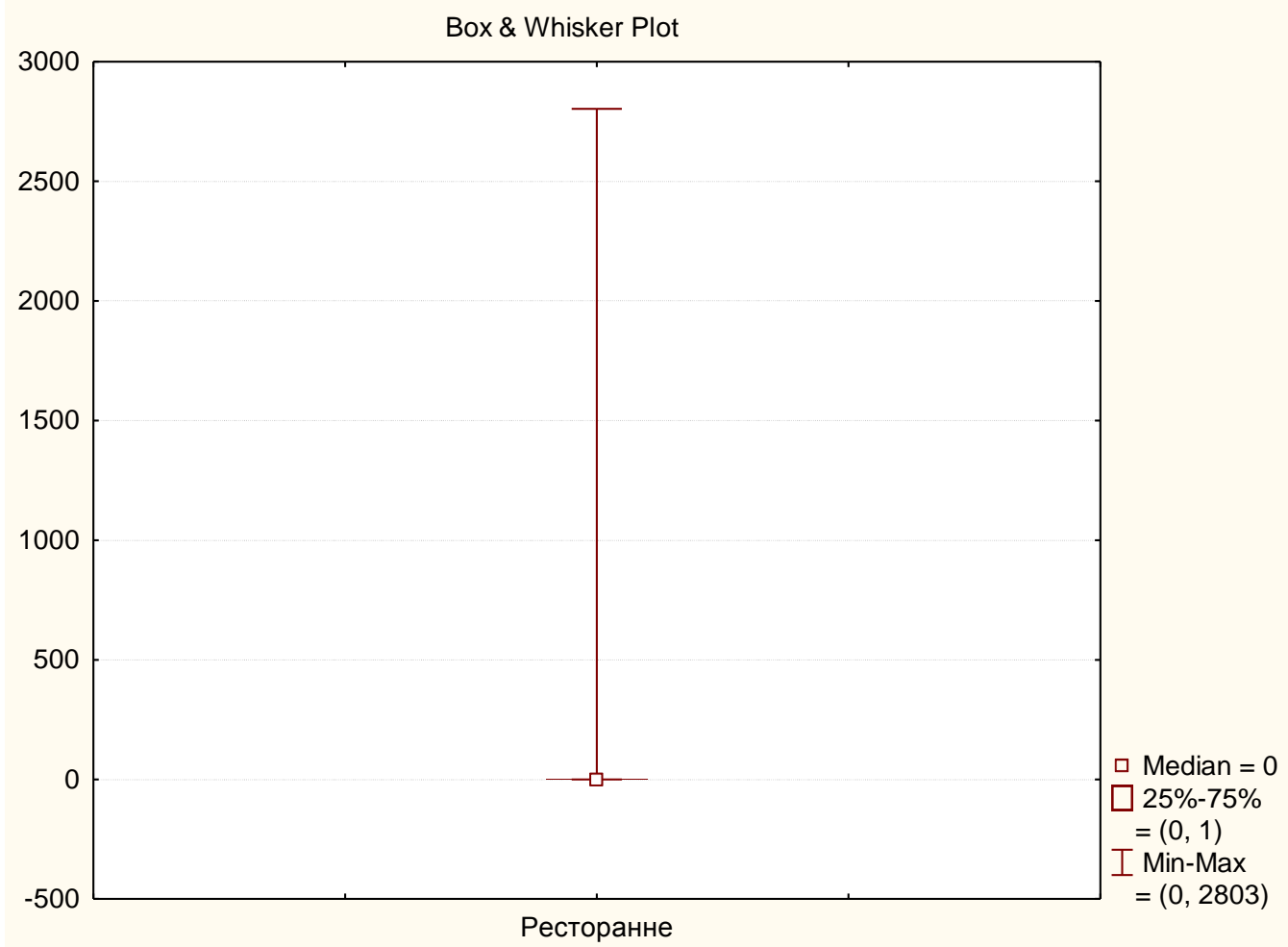

Рис. 3. Діаграма розмаху (bоx \& whisker plot) кількості закладів ресторанного господарства у населених пунктах Харківської області за 2019 р. (складено авторами за даними [17,18]) 


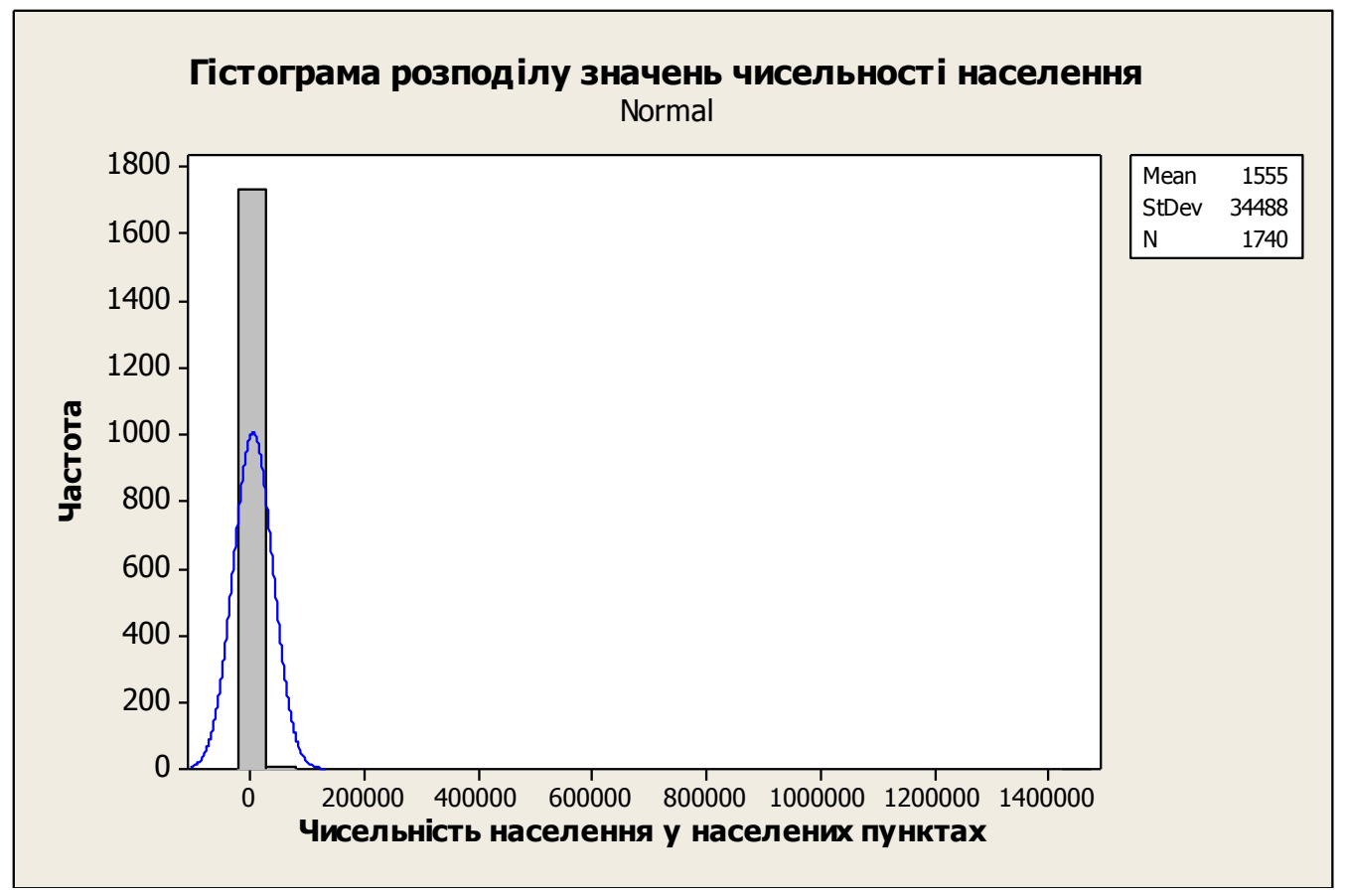

Рис. 4. Гістограма розподілу значень чисельності населення у населених пунктах Харківської області за 2019 р. (складено авторами за даними $[17,18]$ )

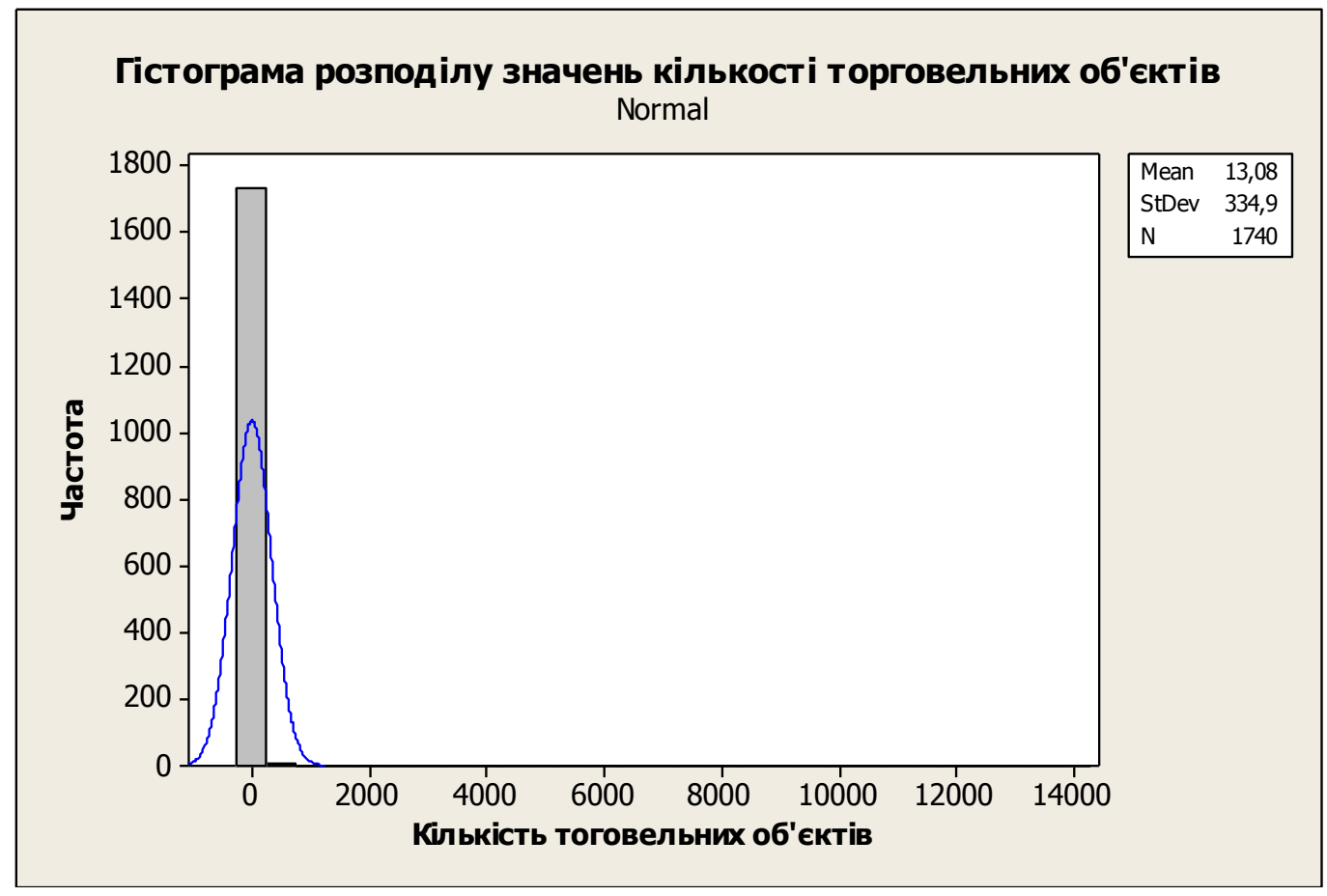

Рис. 5. Гістограма розподілу значень кількості об'єктів торгівлі у населених пунктах Харківської області за 2019 р. (складено авторами за даними [17, 18])

Наступим кроком є аналіз ступеня моноцентричності у розрізі районів Харківської області. Відповідно до Розпорядження Кабінету Міністрів України № 725-р від 12 червня 2020 р. «Про визначення адміністративних центрів та затвердження територій територіальних громад Харківської області» у Харківській області сформовано 56 територіальних громад [20], а Постановою Верховної Ради України № 807IX «Про утворення та ліквідацію районів» від
17.07.2020 р. у Харківській області було сформовано 7 районів замість 27 [21]. Для розуміння і порівняння ступеня моноцентричності у розрізі районів Харківської області були обрані окремі параметри описової статистики, а саме: середнє арифметичне значення, медіана, середньоквадратичне відхилення, коефіцієнт варіації, коефіцієнт асиметрії, коефіцієнт ексцеcy. 


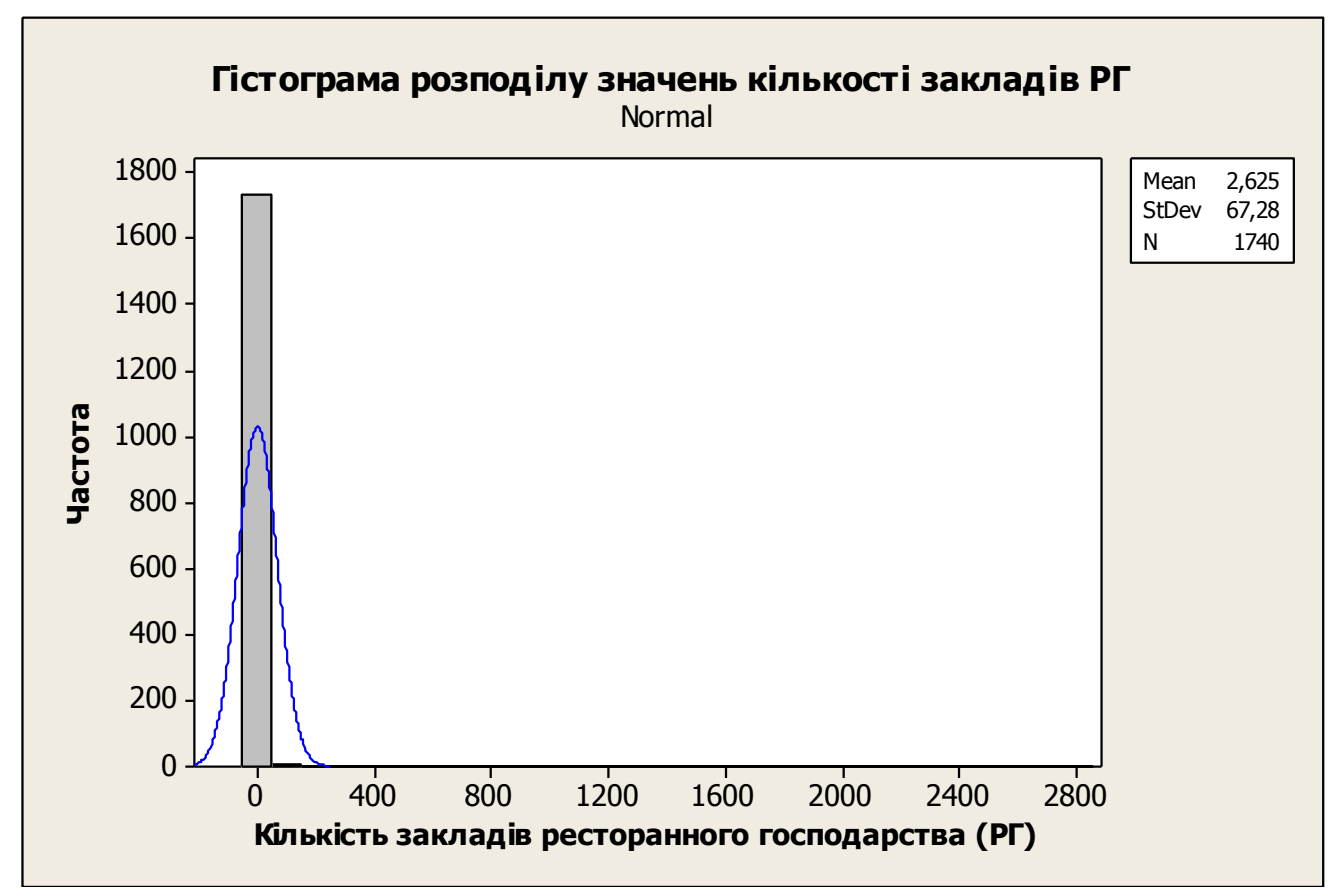

Рис. 6. Гістограма розподілу значень кількості закладів ресторанного господарства у населених пунктах Харківської області за 2019 р. (складено авторами за даними $[17,18]$ )

Параметри описової статистики показника чисельності населення у населених пунктах свідчать про те, що розподіл показника у кожному районі Харківської області не є нормальним (таблиця 2). Так, медіана не дорівнює середньому арифметичному значенню, проте найбільш наближеним до цього рівняння $\epsilon$ Богодухівський район (різниця між середнім арифметичним значенням та медіаною становить 271,9 од.), найбільш віддаленим $\epsilon$ Харківський район (8589,9 од.). Для жодного району коефіцієнт асиметрії не дорівнює 0 , проте найбільш симетричним розподіл показниками виявився для Богодухівського та
Чугуївського районів, а найменш симетричним - для Харківського та Куп'янського районів. Коефіцієнт ексцесу також найбільш наближений до 0 для Богодухівського та Чугуївського районів, а найбільш віддалений - для Харківського та Куп'янського районів. Середньоквадратичне відхилення, коефіцієнт варіації підтверджує нерівномірність розподілу чисельності населення, проте найменші значення цих параметрів описової статистики характерні для Богодухівського та Красноградського районів, а найбільші значення саме для Харківського району.

Таблиия 2

Параметри описової статистики показника чисельності населення у населених пунктах у розрізі районів Харківської області за 2019 р. (складено авторами за даними [17, 18])

\begin{tabular}{|l|c|c|c|c|c|c|}
\hline \multicolumn{1}{|c|}{ Райони } & $\begin{array}{c}\text { Середнє } \\
\text { арифметичне } \\
\text { значення } \\
\text { (Меаn) }\end{array}$ & $\begin{array}{c}\text { Медіана } \\
(\mathrm{Me})\end{array}$ & $\begin{array}{c}\text { Середньо- } \\
\text { квадратичне } \\
\text { відхилення ( } \sigma)\end{array}$ & $\begin{array}{c}\text { Коефіцієнт } \\
\text { варіації }\end{array}$ & $\begin{array}{c}\text { Коефіцієнт } \\
\text { асиметрії } \\
\text { (As) }\end{array}$ & $\begin{array}{c}\text { Коефіцієнт } \\
\text { ексцесу } \\
(\text { Es) }\end{array}$ \\
\hline Богодухівський & 378,9 & 107 & 1205,1 & 318,1 & 8,8 & 91,9 \\
\hline Ізюмський & 835,3 & 174 & 3990,1 & 477,7 & 10,3 & 117,9 \\
\hline Красноградський & 515,2 & 189,5 & 1618,5 & 314,1 & 10,0 & 118,9 \\
\hline Купянський & 536,8 & 133 & 3534,1 & 658,4 & 15,6 & 249,9 \\
\hline Лозівський & 658,3 & 134 & 4189,4 & 636,4 & 11,8 & 149,0 \\
\hline Харківський & 8554,9 & 265 & 99577,3 & 1163,9 & 14,3 & 206,4 \\
\hline Чугуївський & 929,3 & 199,0 & 3010,7 & 324,0 & 7,4 & 66,3 \\
\hline
\end{tabular}

Параметри описової статистики для показника кількості об’єктів торгівлі у населених пунктах також свідчать про невідповідність нормальному розподілу значень показника в усіх районах Харківської області (таблиця 3). Середнє арифметичне значення та медіана не дорівнюють один одному, проте наближаються для Богодухівського району, найбільш віддалені для Харківського району. Коефіцієнт асиметрії найбільш наближений до 0 в Ізюмському та Чугуївському районах, найбільш віддалений у Куп'янському та Харківському районах. Те ж саме можна сказати і про коефіцієнт ексцесу. Ступінь розсіювання найменший у Богодухівського, Чугуївсько- 
го, Красноградського районів, а найбільш розсіяність характерна для Харківського району.

Параметри описової статистики для показника кількості об'єктів ресторанного господарства у населених пунктах також обумовлюють ненормальний розподіл значень показника в усіх районах Харківської області (таблиця 4). Середнє арифметичне значення та медіана наближаються один до одного у Богодухівському, Куп'янському районах, віддаляються у Харківському районі. Коефіцієнт асиметрії найбільш наближений до 0 у Богодухівському, Крас- ноградському районах, найбільш віддалений у Харківському районі. Те ж саме можна сказати і про коефіцієнт ексцесу. Стандартне відхилення та коефіці$\epsilon$ нт варіації найменший у Богодухівському, Красноградському районах, а найбільший у Харківського, Куп'янського районах. Аналізуючи усі три наведені таблиці, слід зазначити, найбільший внесок у ненормальний розподіл значень показників вносить Харківський район, який включає обласний центр, що значно відрізняється від решти населених пунктів за згаданими показниками.

Таблиця 3

Параметри описової статистики показника кількості об'єктів тордівлі у населених пунктах у розрізі районів Харківської області за 2019 р. (складено авторами за даними [17, 18])

\begin{tabular}{|c|c|c|c|c|c|c|}
\hline Райони & $\begin{array}{c}\text { Середнє } \\
\text { арифметичне } \\
\text { значення } \\
\text { (Mean) }\end{array}$ & $\begin{array}{c}\text { Медіана } \\
\text { (Ме) }\end{array}$ & $\begin{array}{c}\text { Середньо- } \\
\text { квадратичне } \\
\text { відхилення }(\sigma)\end{array}$ & $\begin{array}{c}\text { Коефіцієнт } \\
\text { варіації }\end{array}$ & $\begin{array}{c}\text { Коефіцієнт } \\
\text { асиметрії } \\
\text { (As) }\end{array}$ & $\begin{array}{c}\text { Коефіцієнт } \\
\text { ексцесу } \\
\text { (Es) }\end{array}$ \\
\hline Богодухівський & 3,2 & 0,0 & 17,3 & 535,1 & 10,6 & 124,2 \\
\hline Ізюмський & 7,4 & 1,0 & 42,3 & 568,9 & 9,0 & 85,1 \\
\hline Красноградський & 4,6 & 1,0 & 23,8 & 511,6 & 10,3 & 119,9 \\
\hline Куп’янський & 4,9 & 1,0 & 39,8 & 811,9 & 14,4 & 221,9 \\
\hline Лозівський & 3,8 & 0,0 & 23,1 & 612,7 & 9,8 & 101,0 \\
\hline Харківський & 75,3 & 1,0 & 969,9 & 1287,8 & 14,3 & 205,8 \\
\hline Чугуївський & 5,2 & 1,0 & 20,0 & 387,1 & 8,2 & 80,0 \\
\hline
\end{tabular}

Таблиияя 4

Параметри описової статистики показника кількості об’єктів ресторанного господарства у населених пунктах у розрізі районів Харківської області за 2019 р. (складено авторами за даними [17, 18])

\begin{tabular}{|c|c|c|c|c|c|c|}
\hline & $\begin{array}{c}\text { Середнє } \\
\text { арифметичне } \\
\text { значення } \\
\text { (Mean) }\end{array}$ & $\begin{array}{c}\text { Медіана } \\
\text { (Ме) }\end{array}$ & $\begin{array}{c}\text { Середньо- } \\
\text { квадратичне } \\
\text { відхилення (б) }\end{array}$ & $\begin{array}{c}\text { Коефіцієнт } \\
\text { варіації }\end{array}$ & $\begin{array}{c}\text { Коефіцієнт } \\
\text { асиметрії } \\
\text { (As) }\end{array}$ & $\begin{array}{c}\text { Коефіцієнт } \\
\text { ексцесу } \\
\text { (Es) }\end{array}$ \\
\hline Богодухівський & 0,7 & 0,0 & 2,1 & 291,5 & 6,8 & 60,7 \\
\hline Ізюмський & 1,2 & 0,0 & 4,8 & 394,4 & 8,5 & 81,0 \\
\hline Красноградський & 0,8 & 0,0 & 2,6 & 314,4 & 7,5 & 68,8 \\
\hline Куп’янський & 0,7 & 0,0 & 3,4 & 459,7 & 13,0 & 190,9 \\
\hline Лозівський & 0,8 & 0,0 & 4,0 & 500,2 & 10,5 & 119,0 \\
\hline Харківський & 5,6 & 0,0 & 53,9 & 961,5 & 14,1 & 200,1 \\
\hline Чугуївський & 1,3 & 0,0 & 4,7 & 350,5 & 7,9 & 74,6 \\
\hline
\end{tabular}

Висновки. Таким чином, можна зробити висновки, що одним з методів виявлення ступеня моноцентричності/поліцентричності регіонального розвитку $\epsilon$ одновимірний статистичний аналіз, що характеризує розподіл значень одного показника. На прикладі торговельного обслуговування населення Харківської області було застосовано даний метод. Для дослідження використані показники чисельності населення, кількості закладів торгівлі, ресторанного господарства у розрізі населених пунктів Харківської області, за якими розраховано наступні параметри описової статистики: медіана, мода, середнє арифметичне значення, дисперсія, середньоквадратичне відхилення, коефіцієнт варіації, коефіцієнт асиметрії, коефіцієнт асиметрії, коефіцієнт ексцесу.

За результатами проведення одновимірного статистичного аналізу встановлено, що показники чисельності населення, кількості закладів торгівлі, ресто- ранного господарства по Харківській області в цілому не відповідають нормальному розподілу змінної. Медіана не дорівнює середньому арифметичному, дуже високі значення дисперсії, коефіцієнту варіації, а коефіцієнти асиметрії та ексцесу не дорівнюють 0 . Все це свідчить про значну моноцентричність регіонального розвитку у Харківській області. У розрізі адміністративних районів Харківської області також для жодного району не характерний нормальний розподіл показників, дуже сильно виділяється Харківський район, який за багатьма параметрами описової статистики більший приблизно у 2 рази до найближчих до нього інших районів. Місто Харків за новим адміністративно-територіальним поділом належить до Харківського району. Найбільш наближеними до нормального розподілу є Богодухівський, Чугуївський райони. Отримані результати підтверджують надмірну моноцентричність регіонального розвитку. 
За цією методикою можна аналізувати розподіл закладів торгівлі, ресторанного господарства чисельності населення у розрізі інших регіонів України за зробити порівняльно-географічну характеристику.
Дане дослідження також може бути основою при проведення майбутніх досліджень 3 переходу до поліцентричної моделі розвитку Харківської області.

\section{Список використаних джерел:}

1. Барановский Н.А. Территориальная организация передвижных форм обслуживания сельского населения Черниговской области: автореф. дис... на соискание ученой степени канд. геогр. наук: спец.: 11.00 .02 «Экономическая и социальная география». - К., 1992. - 22 с.

2. Білокінь Т.Г. Регулювання розвитку регіонального споживчого ринку: автореф. дис. ... канд. екон. наук: 08.00.05 / Т. Г. Білокінь. - Черкаси, 2012. - 20 с.

3. Голвазін О.М. Формування поліцентричного розвитку України в умовах територіальної концентрації економіки : дис. ... кандидата економ. наук: 08.00.03 / О.М. Голвазін. - Київ, 2018. - 244 с.

4. Голіков А.П. Математичні методи в географії / А.П. Голіков, І.Г. Черваньов, А.М. Трофімов. - Харків: Видавництво при Харківському університеті, 1986. - 143 с.

5. Грицевич В.С. Статистичні методи в суспільній географії: навч. посібник / В.С. Грицевич, Л.І. Котик. Львів: ЛНУ ім. І. Франка, 2016. - 92 с.

6. Запотоцька І.В. Територіальна організація соціальної сфери Черкаської області та основні напрямки ії вдосконалення [Текст]: автореф. дис... на здобуття наук. ступеня канд. геогр. наук: 11.00 .02 / I.В. Запотоцька. Київський національний університет імені Тараса Шевченка. - К., 2007. - 21 с.

7. Иванченко В.П. Состояние и пути совершенствования торговли в средних городах (на примере моноотраслевых городов Донецкой области): автореф. дис. на соискание ученой степени канд. эконом. наук: спец. 08.00.05 «Экономика, организация управления и планирование торговли» / В.П. Иванченко. - К., $1974 .-21$ c.

8. Кобилін П.О. Територіальні особливості системи торговельного обслуговування населення Харківської області: дис. ... кандидата геогр. наук: 11.00 .02 / П.О. Кобилін. - Х., 2017. - 386 с.

9. Колосінський Є.Ю. Трансформація територіальної організації торговельної сфери регіону в умовах розвитку постіндустріальної економіки : автореф. дис. ... канд. екон. наук : 08.00.05 / Є.Ю. Колосінський. - Ужгород, 2012. $-20 \mathrm{c}$.

10. Корнус О.Г. Сфера обслуговування населення Сумської області: суспільно-географічні аспекти: Монографія / О.Г. Корнус, К.А. Нємець, Л.М. Нємець, А.О. Корнус. - Х. - Суми.: Видавництво ХНУ ім. В.Н. Каразіна, 2009 . -228 с.

11. Опря А.Т. Статистика: Навчальний посібник / А.Т. Опря. - Київ: ЦНЛ, 2012. - 448с.

12. Полинська Г.А. Інформаційні системи маркетингу / Г.А. Полинська. - Київ: ЮРАЙТ, 2016. - 324 с.

13. Моніторинг соціально-економічного розвитку регіонів за 2019 рік [Електронний ресурс]. - Режим доступу : https://www.minregion.gov.ua/napryamki-diyalnosti/derzhavna-rehional-na-polityka/monitorynh/monitorynhmonitorynh/reytingova-otsinka-regioniv/rejtyngova-oczinka-za-2019-rik-prezentaczijni-materialy/

14. Нємець К. Міста Харківщини: моноцентрична чи поліцентрична модель просторового розвитку регіону (перспективи та загрози) / К. Нємець, К. Сегіда, Н. Гусєва // Урбаністична Україна: в епіцентрі просторових змін: монографія / за ред. К. Мезенцева, Я. Олійника, Н. Мезенцевої. - Київ: Видавництво «Фенікс», 2017. С. 65-97.

15. Нємець К.А. Просторовий аналіз у суспільній географії: нові підходи, методи, моделі: монографія / К.А. Нємець, Л.М. Нємець. - Х.: ХНУ імені В.Н. Каразіна, 2013. - 228 с.

16. Осіпчук I.О. Територіальна організація торговельного обслуговування населення Рівненської області [Текст]: автореф. дис... на здобуття наук. ступеня канд. геогр. наук: 11.00 .02 / I.О. Осіпчук. - Київський національний університет імені Тараса Шевченка. - К., 2013. - 20 с.

17. Офіційний сайт Головного управління статистики у Харківській області [Електронний ресурс]. - Режим доступу: http://kh.ukrstat.gov.ua/

18. Офіційний сайт Харківської обласної державної адміністрації [Електронний ресурс]. - Режим доступу: http://www.kharkivoda.gov.ua

19. Пилипенко І.О. Центро-периферійні процеси і структури в територіальній організації суспільства: дис. ... доктора геогр. наук: 11.00.02 / І.О. Пилипенко. - Одеса, 2015. - 304 с.

20. «Про визначення адміністративних центрів та затвердження територій територіальних громад Харківської області» / Розпорядження Кабінету Міністрів України № 725-р від 12 червня 2020 р. [Електронний ресурс]. - Режим доступу: https://www.kmu.gov.ua/npas/pro-viznachennya-administrativnih-centriv-ta-zatverdzhennyateritorij-teritorialnih-gromad-harkivskoyi-oblasti-i120620-725

21. «Про утворення та ліквідацію районів» / Постанова Верховної Ради України № 807-IX від 17.07.2020 [Електронний ресурс]. - Режим доступу: https://zakon.rada.gov.ua/laws/show/807-20\#Text

22. Стратегія розвитку Харківської області на період до 2020 року / Рішення Харківської обласної ради №1151 VI від 05 березня 2015 року [Електронний ресурс]. - Режим доступу: http://old.kharkivoda.gov.ua/documents/16203/1088.pdf 
23. Территориальная организация производства товаров и услуг: в 2 т. / Общ.ред. А.И. Кочерга. - Киев: Наукова думка, 1987. Т. 1 : Производство и обращение товаров народного потребления. - Киев, 1987. - 262 с. - С. 188.

24. Тичинська Л.М., Черепащук А.А. Теорія ймовірностей. Частина 1. Історичні екскурси та основні теоретичні відомості. - Вінниця: ВНТУ, 2010. - 112 с.

25. Шаблій O.I. Математичні методи в соціально-економічній географії: Посібник для студентів геогр. і екон. фак. / O.І. Шаблій. - Львів: Світ, 1994 . - 303 с.

26. Friedmann, J. Territory and Function: The evolution of regional planning / J. Friedmann. - London, Edward Arnold Ltd, 1979. $-355 \mathrm{c}$.

27. Niemets L. Transition Features to the Polycentric Development of the Region: Technique and Practice of the Research / L. Niemets, K. Niemets, K. Kravchenko, L. Kliuchko, P. Kobylin. // Proceedings of the 33nd International Business Information Management Association Conference (IBIMA) (Granada, Spain, 10-11 April 2019) / Editor Khalid S. Soliman. - Granada, International Business Information Management Association (IBIMA), 2019. - p. 3093-3101.

28. Perroux F. Economic space: theory and applications / F. Perroux // Quarterly Journal of Economics. - 1950. V. 64. - P. 20-32.

29. Peptenatu D., Draghici C. (2012). Characteristics of entrepreneurial profile in some emergent territorial structures in Romania // Actual Problems of Economics. - № 12(138). - P. 448-458.

30. Szymańska D. Central and Eastern Europe in the light of the spatial distribution of luxury stores - some problems / D. Szymańska, S. Środa-Murawska // Часопис соціально-економічної географії: міжрег. зб. наук. праць. - Харків: ХНУ імені В.Н. Каразіна, 2013. - Вип. 15(2). - С. 48-56.

31. Veneri P., Burgalassi D. (2012). Questioning polycentric development and its effects. Issues of definition and measurement for the Italian NUTS 2 Regions / P. Veneri, D. Burgalassi // European Planning Studies. - Vol. 20, № 6. - P. 1017-1037.

\section{References:}

1. Baranovskiy, N.A. (1992). Territorialnaya organizatsiya peredvizhnykh form obsluzhivaniya selskogo naseleniya Chernigovskoy oblasti [Territorial organization of mobile forms of service for the rural population of the Chernigov region]. Extended abstract of candidate's thesis. Kyiv, 22 p. [in Russian].

2. Bilokin, T.H. (2012). Rehulyuvannya rozvytku regionalnoho spozhyvchoho rynku [Regulation of the regional consumer market development]. Extended abstract of candidate's thesis. Cherkasy, 20 p. [in Ukrainian].

3. Holvazin, O.M. (2018). Formuvannya politsentrychnoho rozvytku Ukrainy v umovakh terytorialnoi kontsentratsii ekonomiky [Formation of polycentric development of Ukraine in the conditions of territorial concentration of economy]. Candidate's thesis. Kyiv, 244 p. [in Ukrainian].

4. Holikov, A.P., Chervaniov, I.H., \& Trofimov, A.M. (1986). Matematychni metody v geografii [Mathematical methods in geography]. Kharkiv, Vydavnytstvo pry Kharkivskomu universyteti, 143 p. [in Ukrainian].

5. Hrytsevych, V.S., \& Kotyk, L.I. (2016). Statystychni metody v suspilniy geografii: navch. posibnyk [Statistical methods in human geography: textbook]. Lviv: LNU im. I. Franka, 92 p. [in Ukrainian].

6. Zapototska, I.V. Terytorialna organizatsiya sotsialnoi sfery Cherkaskoi oblasti ta osnovni napryamky yiyi vdoskonalennya [Territorial organization of the social sphere of Cherkasy region and the main directions of its improvement]. Extended abstract of candidate's thesis. Kyiv, 21 p. [in Ukrainian].

7. Ivanchenko, V.P. (1974). Sostoyanie i puti sovershenstvovaniya torgovli v srednikh gorodakh (na primere monootraslevykh gorodov Donetskoy oblasti) [State and ways of improving trade in medium-sized cities (on the example of single-industry cities of Donetsk region)] Extended abstract of candidate's thesis. Kyiv, 21 p. [in Russian].

8. Kobylin, P.O. (2017). Terytorialni osoblyvosti systemy torhovelnoho obsluhovuvannya naselennya Kharkivskoi oblasti [Territorial features of the system of population trade services of Kharkiv region]. Candidate's thesis. Kharkiv, 386 p. [in Ukrainian].

9. Kolosinskyi, Ye.Yu. (2012). Transformatsiya terytorialnoi organizatsii torhovelnoi sfery regionu v umovakh rozvytku postindustrialnoi ekonomiky [Transformation of the territorial organization of the trade sphere of the region in the development of post-industrial economy]. Extended abstract of candidate's thesis. Uzhhorod, 20 p. [in Ukrainian].

10. Kornus, O.H., Niemets, K.A., Niemets, L.M., \& Kornus A.O. (2009). Sfera obsluhovuvannya naselennya Sumskoi oblasti: suspilno-geografichni aspekty: Monografiya [Population Service Sphere of the Sumy region: HumanGeographical aspects: Monograph]. Kharkiv - Sumy, Vydavnytstvo KHNU im. V.N. Karazina, 228 p. [in Ukrainian].

11. Oprya, A.T. (2012). Statystyka: Navchalnyi posibnyk [Statistics: Textbook]. Kyiv, TSNL, 448 p. [in Ukrainian].

12. Polynska, H.A. (2016). Informatsiyni systemy marketynhu [Marketing information systems]. Kyiv: YURAYT, 324 p. [in Ukrainian].

13. Monitorynh sotsialno-ekonomichnoho rozvytku regioniv za 2019 rik [Monitoring of socio-economic development of regions in 2019]. Retrieved from: https://www.minregion.gov.ua/napryamki-diyalnosti/derzhavna-rehional-napolityka/monitorynh/monitorynh-monitorynh/reytingova-otsinka-regioniv/rejtyngova-oczinka-za-2019-rikprezentaczijni-materialy/ [in Ukrainian]. 
14. Niemets, K., Sehida, K., \& Husieva, N. (2017). Mista Kharkivshchyny: monotsentrychna chy politsentrychna model prostorovoho rozvytku regionu (perspektyvy ta zahrozy) [Cities of Kharkiv region: monocentric or polycentric model of spatial development of the region (perspectives and threats)]. Urbanistychna Ukrayina: v epitsentri prostorovykh zmin - Urban Ukraine: at the epicenter of spatial change. K. Mezentsev, Ya. Oliynyk, N. Mezentseva (Eds). Kyiv: Vydavnytstvo «Feniks», p. 65-97 [in Ukrainian].

15. Niemets, K.A., \& Niemets, L.M. (2013). Prostorovyi analiz u suspilniy geografii : novi pidkhody, metody, modeli: monografiya [Spatial analysis in social geography: new approaches, methods, models: monograph]. Kharkiv, KhNU imeni V.N. Karazina, 228 p. [in Ukrainian].

16. Osipchuk, I.O. (2013). Terytorialna organizatsiya torhovelnoho obsluhovuvannya naselennya Rivnenskoi oblasti [Territorial organization of population trade services of Rivne region]. Extended abstract of candidate's thesis. Kyiv, 20 p. [in Ukrainian].

17. Ofitsiynyi sayt Holovnoho upravlinnya statystyky u Kharkivskiy oblasti [Official site of the Main Department of Statistics in Kharkiv region]. Retrieved from http://kh.ukrstat.gov.ua/ [in Ukrainian].

18. Ofitsiynyy sayt Kharkivskoi oblasnoi derzhavnoi administratsii [Official site of the Kharkiv Regional State Administration]. Retrieved from http://www.kharkivoda.gov.ua [in Ukrainian].

19. Pylypenko, I.O. (2015). Tsentro-peryferiyni protsesy i struktury v terytorialniy organizatsii suspilstva [Centerperipheral processes and structures in the territorial organization of the society]. Extended abstract of candidate's thesis. Odessa, 304 p. [in Ukrainian].

20. Pro vyznachennya administratyvnykh tsentriv ta zatverdzhennya terytoriy terytorialnykh hromad Kharkivskoi oblasti : Rozporyadzhennya Kabinetu Ministriv Ukrayiny № 725-r vid 12 chervnya 2020 r. [On the definition of administrative centers and approval of the territories of territorial communities of Kharkiv region: Order of the Cabinet of Ministers of Ukraine № 725-r from June 12, 2020]. Retrieved from https://www.kmu.gov.ua/npas/proviznachennya-administrativnih-centriv-ta-zatverdzhennya-teritorij-teritorialnih-gromad-harkivskoyi-oblastii120620-725 [in Ukrainian].

21. Pro utvorennya ta likvidatsiyu rayoniv: Postanova Verkhovnoi Rady Ukrainy № 807-IX vid 17.07.2020 [On the formation and liquidation of districts: Resolution of the Verkhovna Rada of Ukraine № 807-IX from 17.07.2020]. Retrieved from https://zakon.rada.gov.ua/laws/show/807-20\#Text [in Ukrainian].

22. Stratehiya rozvytku Kharkivskoi oblasti na period do 2020 roku: Rishennya Kharkivskoi oblasnoyi rady №1151-VI vid 05 bereznya 2015 roku [Kharkiv Region Development Strategy for the Period till to 2020: Decision of the Kharkiv Regional Council №1151-VI from March 5, 2015]. Retrieved from http://old.kharkivoda.gov.ua/documents/16203/1088.pdf [in Ukrainian].

23. Kocherga, I. (Eds.) (1987). Territorialnaya organizatsiya proizvodstva tovarov i uslug [Territorial organization of production of goods and services] (Vols. 1-2). Vols. 1: Proizvodstvo i obrashchenie tovarov narodnogo potrebleniya[Production and circulation of consumer goods]. Kyiv: Naukova dumka, 262 p. [in Russian].

24. Tychynska, L.M., \& Cherepashchuk, A.A. (2010). Teoriya ymovirnostey. Chastyna 1. Istorychni ekskursy ta osnovni teoretychni vidomosti [Probability theory. Part 1. Historical excursions and basic theoretical information]. Vinnytsia, VNTU, 112 p. [in Ukrainian].

25. Shabliy, O.I. (1994). Matematychni metody v sotsialno-ekonomichniy geografii: Posibnyk dlya studentiv geogr.i ekon. fak. [Mathematical methods in human geography: A guide for geography and economics students]. Lviv, Svit, 303 p. [in Ukrainian].

26. Friedmann, J. (1979). Territory and Function: The evolution of regional planning, London, Edward Arnold, Ltd, 355.

27. Niemets, L., Niemets, K., Kravchenko, K., Kliuchko, L., \& Kobylin, P. (2019). Transition Features to the Polycentric Development of the Region: Technique and Practice of the Research. Proceedings of the 33nd International Business Information Management Association Conference (IBIMA) (Granada, Spain, 10-11 April 2019). Editor Khalid S. Soliman. Granada, International Business Information Management Association (IBIMA), p. 3093-3101

28. Perroux, F. (1950). Economic space: theory and applications. Quarterly Journal of Economics, 64, $20-32$.

29. Peptenatu, D., \& Draghici, C. (2012). Characteristics of entrepreneurial profile in some emergent territorial structures in Romania. Actual Problems of Economics, 12(138), 448-458.

30. Szymańska, D., \& Środa-Murawska, S. (2013). Central and Eastern Europe in the light of the spatial distribution of luxury stores - some problems. Chasopys sotsialno-ekonomichnoi geografii - Human Geography Journal, 15(2), 48-56.

31. Veneri, P., \& Burgalassi, D. (2012). Questioning polycentric development and its effects. Issues of definition and measurement for the Italian NUTS 2 Regions. European Planning Studies, 20, № 6, 1017-1037.

Надійшла до редколегї 28.10.2020 p.

\section{About the authors:}

Pavlo Kobylin - PhD (Geography), Associate Professor of the Department of Human Geography and Regional Studies, V.N. Karazin Kharkiv National University, Svobody Sq., 4, Kharkiv, 61022, Ukraine, kobilin333@gmail.com, https://orcid.org/0000-0001-9718-5838 
Nataliia Dobrovolska - PhD (Geography), Associate Professor of the Department of Tourism and Hotel Business, Kharkiv lnstitute of Trade and Economics of Kyiv National University of Trade and Economics, Otakar Yarosh lane, 8, Kharkiv, 61045, Ukraine; Associate Professor of the Department of Human Geography and Regional Studies, V.N. Karazin Kharkiv National University, Svobody Sq., 4, Kharkiv, 61022, Ukraine, natalie.dobrovolskaya@gmail.com, https://orcid.org/0000-0001-5583-2179

Iryna Skryl - PhD (Geography), Associate Professor of the Department of Human Geography and Regional Studies, V.N. Karazin Kharkiv National University, Svobody Sq., 4, Kharkiv, 61022, Ukraine, skril403@gmail.com, https://orcid.org/0000-0002-2010-0872

Volodymyr Redin - PhD (Geography), Associate Professor of the Department of Human Geography and Regional Studies, V.N. Karazin Kharkiv National University, Svobody Sq., 4, Kharkiv, 61022, Ukraine, vadim.redin@karazin.ua, https://orcid.org/0000-0002-1580-7662

\section{Об авторах:}

Павел Кобылин - кандидат географических наук, доцент кафедры социально-экономической географии и регионоведения, Харьковский национальный университет имени В.Н. Каразина, площадь Свободы, 4, 61022 , Украина, kobilin333@gmail.com, https://orcid.org/0000-0001-9718-5838

Наталья Добровольская - кандидат географических наук, доцент кафедры туристического и гостиничного бизнеса, Харьковский торгово-экономический институт Киевского национального торговоэкономического университета, пер. Отакара Яроша, 8, г. Харьков, 61045, Украина; доцент кафедры социальноэкономической географии и регионоведения, Харьковский национальный университет имени В.Н. Каразина, площадь Свободы, 4, 61022, Украина, natalie.dobrovolskaya@gmail.com, https://orcid.org/0000-0001-5583-2179

Ирина Скрыль - кандидат географических наук, доцент кафедры социально-экономической географии и регионоведения, Харьковский национальный университет имени В.Н. Каразина, площадь Свободы, 4, 61022, Украина, skril403@gmail.com, https://orcid.org/0000-0002-2010-0872

Владимир Редин - кандидат географических наук, доцент кафедры социально-экономической географии и регионоведения, Харьковский национальный университет имени В.Н. Каразина, площадь Свободы, 4, 61022, Украина, vadim.redin@karazin.ua, https://orcid.org/0000-0002-1580-7662 